SCIREA Journal of Forestry

http://www.scirea.org/journal/Forestry

July 5, 2021

Volume 2, Issue 1, February 2021

\title{
Socioecological outcomes from Community Forestry: Insights from Nepalese Stakeholders
}

\author{
${ }^{1}$ Dr Bhagwan Dutta Yadav , ${ }^{2}$ Dr Krishna Kumar Shrestha, ${ }^{3}$ Bishnu Prasad Acharya \\ ${ }^{1}$ Research Associate, Support For Development, New Zealand \\ ${ }^{2}$ Associate Professor, Faculty Focal Person, UNSW The University of New South, Wales, \\ UNSW Sydney, NSW 2052, AUSTRALIA \\ ${ }^{3}$ Divisional Forest Officer, Dadeldhura, Nepal \\ Email : Bhagwanduttayadav@gmail.com,krishna.shrestha@unsw.edu.au, \\ bpa1971@gmail.com
}

\begin{abstract}
Context

Community Forestry (CF) resources possess huge potential for better ecological outcomes to enhance the society's livelihoods world wise. This is achieved only when a Community Forestry Management Plan (CFMP) is designed and actively operated at the local community level. The outcomes of several researches have revealed with the vested interests of the Proficient stakeholders to incorporating in designing of the CFMP.
\end{abstract}

\section{Objectives}

The study aims to identify the local stakeholders' perspectives of the adoption of recent CFMP in regards to their engagement process in designing, development and implementation practice of CFMP that closely related to their livelihoods in terms of on a long-term 
perspective to conserve the productivity of the waters, soil, impact on crop productivity and reduce the local impact on the natural environment and people's health.

\section{Methods}

Random sampling was used to collect 31 CFUGs and 310 households from study sites Siraha, Saptari and Udaypur Districts, Nepal. A two-tail t-test assuming unequal variances was conducted to analyse whether the paired groups are statistically different between each set. A binomial logistic regression that indicates the probability that an observation falls into one of two categories of a dichotomous dependent variable based on one or more independent variables.

\section{Results}

The descriptive correlated variable were perceived as positively significant $(57.1 \%)$ whereas biodiversity conservation negatively significant (34.9\%). The statistical finding of regression analysis forest area per household and broadleaf forest type were statistically significant and the socioecological variables including number in household, agricultural area owned, age of household head, gender, and domestic animals variables were also statistically positively significant.

\section{Conclusion}

The descriptive and regression analysis findings were shown that end-user households received some extant adequate benefits of ecological. When the proposed conceptual model (B) plan will be implemented, it provides critical information to the policy makers and forest managers for designing targeted, appropriate CFMP across regions to improve Community Forestry outcomes in terms of the ecological outcomes that make for good CF governance.

Keywords: Ecological, socioecological outcomes, proficient, societal, CF Governance, CFMP, CF outcomes

\section{Introduction}

The world's land surface is covered by forest landscapes, $31 \%$ of just over 4 billion hectares (FAO, 2010). In Nepal, 40.36\% of the land is covered by forest with $4.38 \%$ in shrubland (DFRS, 2015). The country has 5.9 million hectares of land covered by forest and, of this, 
Community Forest User Groups (CFUGs) manage 1.2 million hectares, or about one quarter of Nepal's forested area (Limbu et al., 2020). The forest is a low-altitude, broadleaved forest in which no species constitutes $60 \%$ of the total basal area (MFS, 2015).

Forests provide many important goods, such as lumber for construction, better air for breathing, and human livelihoods. Forests also offer watershed protection, prevent soil erosion, mitigate climate change, store nutrients, provide habitat for countless animal species and recreation space. The principal objective of global support for forest development is to use the maximum potential environmental conservation without hampering the wellbeing of local people. The importance of exploiting this potential is greater in developing societies where, in most cases, the genuine transfer of power and authority from policy makers and forest administrators to forest based communities is not well-designed or practised even if pledged in policy documents and in the implementation of principles, rules and guidelines (Ostrom, 1999; Ojha et al., 2014). The resources, particularly of community forests, are managed with the participation of multiple stakeholders with heterogeneous power. Despite making a considerable contribution to local and global environmental conservation, the repercussions of weak management practices are high for societal stakeholders (Gilmour, 2016). There are many kinds of stakeholder with competing and, sometimes, overlapping interests. Forest management practices to best address the interests of one category of stakeholders affect the stakes or uses for others. The principles have been applied to Nepalese natural and plantation forest management but do not cover the environmental and social issues associated with processing, products and use beyond the forest gate.

\subsection{Specification of the Research Problems}

Nepal is divided into three geographic regions: the high Himalayas $(16 \%)$ to the north, the middle hills $(68 \%)$, and the lowland Terai $(17 \%)$ to the south. Altitude ranges from 73 to 8,848 meters above mean sea level and includes diverse geo-climatic zones. South Asia, including Nepal, covers diversified climatic regions and experiences an array of climate change impacts (Dobias, 2018). Because high human pressure together with changing land resources, including forest resources, have a distinct impact on food production and ecological resilience. The most threatened areas are the inner Terai, the Terai and hills where species composition and environment and impact flowering seasons, changes in cropping patterns and productivity, changes in water resources, biodiversity conservation/protection, aesthetics, plant species richness, wildlife richness, genetic richness, soil quality, water 
quality and local amenities, forest ecosystems, biodiversity loss, food security, depletion of energy resources, and degradation of rivers.

In this paper, we aim to fill the knowledge gap through a detailed assessment of stakeholders' perspectives of the adoption of the relatively recent Community Forestry Management Plan (CFMP) under the Community Forestry (CF) programme in Nepal. In this undertaking, therefore, we investigate three key questions: (1) what is the stakeholder engagement process in designing, implementation practice of CFMP that makes ecologically friendly to the environment of Nepal under existing policy of government? (2) What is the understanding of key forestry stakeholders on CFMP and how do they perceive its significance and effectiveness to achieve ecological sustainability? (3) What are the more effective strategies to manage CFMP for ecological resilience? This study crucially highlights the role of stakeholders in managing the $\mathrm{CF}$ that benefit to regular and disadvantaged stakeholders in the implementation of CFMP and the Nepalese government policy to make it ecological friendly. The authors refer the ecological sustainability that based on a long-term perspective; the local stakeholders can conserve the productivity of the waters, the soil and reduce the local impact on the natural environment and people's health. To achieve the above objectives and research questions, the following research hypotheses will be scrutinised.

\subsection{Hypotheses}

1. There are Proficient (forest experts) and societal stakeholders who have a significant influence on the ecological outcomes through CFMP.

2. When the appropriate CFMP is implemented more ecological outcomes flow to regular and disadvantaged stakeholders.

3. There is a stakeholder's promise in the formulation of policy and the implementation of CFMP that makes local environment significant.

\section{Previous study}

Many issues have been studied by various scholars of Community Forestry Management. Sapkota et al. (2020) studied capacity development needs assessment (CDNA), which was conducted to understand challenges for CF in Nepal of CFMP. Paudyal et al. (2020) showed that the key forestry stakeholders often hold different, and sometimes conflicting, expectations in relation to forest management policies and management objectives. Baral et al. 
(2019a) examined the role of plans in changing forest conditions. Baral et al. (2019b) reviewed the improvements in forest conditions, economic and social well-being, and low carbon emissions. Nuberg et al. (2019) explained Australia's contribution to Nepal's forestry, with a focus on more recent achievements supporting pathways to realise the potential wealth in Nepal's forests. Sultana et al. (2019) studied the underlying conflict and/or institutional reforms regarding CF management. Anderson and Agrawal (2011) advocated the potential relationships between forest management and property rights allocated to stakeholders involved in forest utilization. Moreover, Acharya et al. (2019) and Adhikari and Agrawal (2013) debate that the availability of Payment of Ecosystem Services-related information with regard to the sustainability of ecosystem service environmental markets values.

The above studies have not considered the precedence of local stakeholders' perceptions regarding ecological outcomes based on CFMP in designing and implementing actions that produce ecological benefits for local stakeholders. This study gives insights into local stakeholders' interactions with the outdoor environment, in general, on CFMP and how they perceive its significance and effectiveness. Stakeholder engagement and the practices of CFMP under prevailing policy make it ecological friendly to the Nepalese environment and stakeholders. It has not been found any study by now that show the substantial relationship between ecological outcomes and CFMP particularly in Inner Terai, Terai and hill regions. The positive and negative outcomes related ecological influences of CFMP that have delivered local stakeholders insights and incorporate to improve ecological management plan through CFMP. This study analyses the stakeholders' engagement, in practice, and the policy in the context of CFMP, the effectiveness, implementation on basis of ecological factors that include social, ecological, and anthropogenic impacts on the on the livelihood of local stakeholders.

\section{Literature Review}

The first purpose of this review is to gain knowledge from the findings of other studies relevant to formulating a research model of the problem of the impact of ecological outcomes from the perspective of Community Forestry User Groups (CFUGs) and their decisionmaking that limits the ecological, social and economic outcomes to regulars and the disadvantaged at the community level. The studies can be benchmarks to support or contradict 
findings from this study. The second purpose is to identify the appropriate analytical model for the problem.

The Nepalese forest management model can make a dynamic contribution both to people and planet by strengthening livelihoods (Charmakar et al., 2021). Appreciating local people as key forest stakeholders and promoting their involvement in decision-making in the design of and implementation of CFMP to generate positive outcomes for livelihoods, by conserving social ecological system, is rare. Nepalese forest management through Community Forestry (CF) that is a very strong principle of Community Based Forest Management (CBFM) in the world. It has been well addressed about generating leadership at the community level (Poudyal et al, 2020). However, it has been an absolutely failure for economic development and the resilience of impact to ecological imbalances from CBFM, particularly in maintaining ecological balance (Poudyal et al., 2020). In contrast, Baynes et al. (2015) found that power of proficient, short term and long term planning and monitoring, manager interest, tree crops effect on agriculture crops. It means ecological balance is about the relationship between biotic things and their physical environment. The ecological potential of a large part of Nepalese forest is under-realised because of a lack of a precise management scheme of forest management (Cedamon et al., 2018). Agrawal et al. (2013) advocated that tapping an appropriate forest management plan would help reduce the opportunity of cost of forests and contribute to maintaining the biosphere, particularly ecological factors such soil, water, fungi, and regeneration, that can support life and the economy by generating income and employment and stimulating infrastructure development at local and national level.

The inter-dependence of ecological, economic, and social sustainability must be recognised in scientific forest management and contribute to the national GDP (Dwyer et al., 2018). Efficient, effective monitoring is required in the implementation of the forest management plan based on silvicultural principles under the guidance of skilled forest specialists that should treat equitably Community Forest Users and implement sustainable forest management (Tudoran and Zotta, 2020).

Forest specialists/forest managers must maintain or enhance ecological outcomes to maintain site productivity and water quality. Forestry operations conducted in a manner that safeguards stream margins and water bodies with the objective of achieving healthy hill and Terai socioecological outcomes (Aryal et al., 2019) are essential. Forest managers should provide for responsible to forests on sustainable forest management principles (Shepherded et al., 2020). The landscape, aesthetics, recreation, and cultural heritage contain many distinctive 
natural features that are important to enhance ecological outcomes. Landscape, amenity and recreation values should be considered in the planning and management of natural and plantation forests for ecological balance and neighbouring areas (Brockerhoff, et al., 2008; Jessica and Antony, 2011). Community consultation is an important component of responsible forest management (Humphries et al., 2020). All industry employees should be qualified in skills that are relevant to the tasks they perform. Ecological forest management is primarily concerned with the establishment and management of local forest. The industry operates in a market environment and managers need the freedom to change management practices to meet changing community preferences in pursuit of maximising ecological returns. Forest managers are free to maximise the economic return without impeding of ecological value (Sing et al., 2018).

Coercion is strongly based on the actors and the structural network of CF. CF networks are affiliated with different CFUG associations that provide a broad field of power options. Therefore, power actors affiliated with formal power networks are responsible for the planning, management and implementation of CF activities even though illegal threats occur to the structures (Krott et al., 2014).

\section{External and internal power of CFUGs and other organisations}

The aim of this commentary is to develop an analytical theory and empirical framework to assess actor power that appears in CF programmes in the developing world including Nepal. The theory illustrates that an agent is the centre of power and the probability is one actor can reside in a social relationship in society in CFUG while he/she holds a position acting as an agent or for an organisation carrying his/her personal will/interest in spite of "resistance, regardless of the basis on which the probability rests" (Krott et al., 2014, p. 36). For example, in $\mathrm{CF}$, the actor can act as an expert/specialist at the implementation level who developed the CFMP and is a policy maker when the actor is working at the apex of the organisation. That actor takes part in the formulation of the constitution and management plan of CF at the CFUG level. Regular stakeholders and the disadvantaged solely depend on forest-based products including ecological outcomes.

\section{Community Forestry Management Plan (CFMP)}

The CF management plan is well outlined with specified objectives that are crucial for successful implementation of the plan. Forestry operations are conducted within a framework determined by an individual management plan for each forest. Setting the objectives of plan 
with adequate information and understanding of the social, cultural, ecological, environmental, and economic conditions is necessary. Hence, CFMP is compatible based on silvicultural principles to reveal the results regarding forest conditions, market demand, society, and particularly communities' people without losing the ecological equilibria (Spies et al., 2020). Effective implementation depends upon a good level of understanding and acceptance by government officials, forest managers, forest workers, machinery operators, communities (including regulars and disadvantaged) and other specialist stakeholders involved in the task (Hoffmann et al., 2018).

The above outline provided a means to develop a conceptual framework specific to the function of the proficient stakeholders in CFUGs. The conceptual framework helps deal with specific problems that pertain to Nepalese CF and institutions in Nepal. The key elements of the power elements in CFUGs, the proficient stakeholders, form the basis of the conceptual model shown in Figure 1.

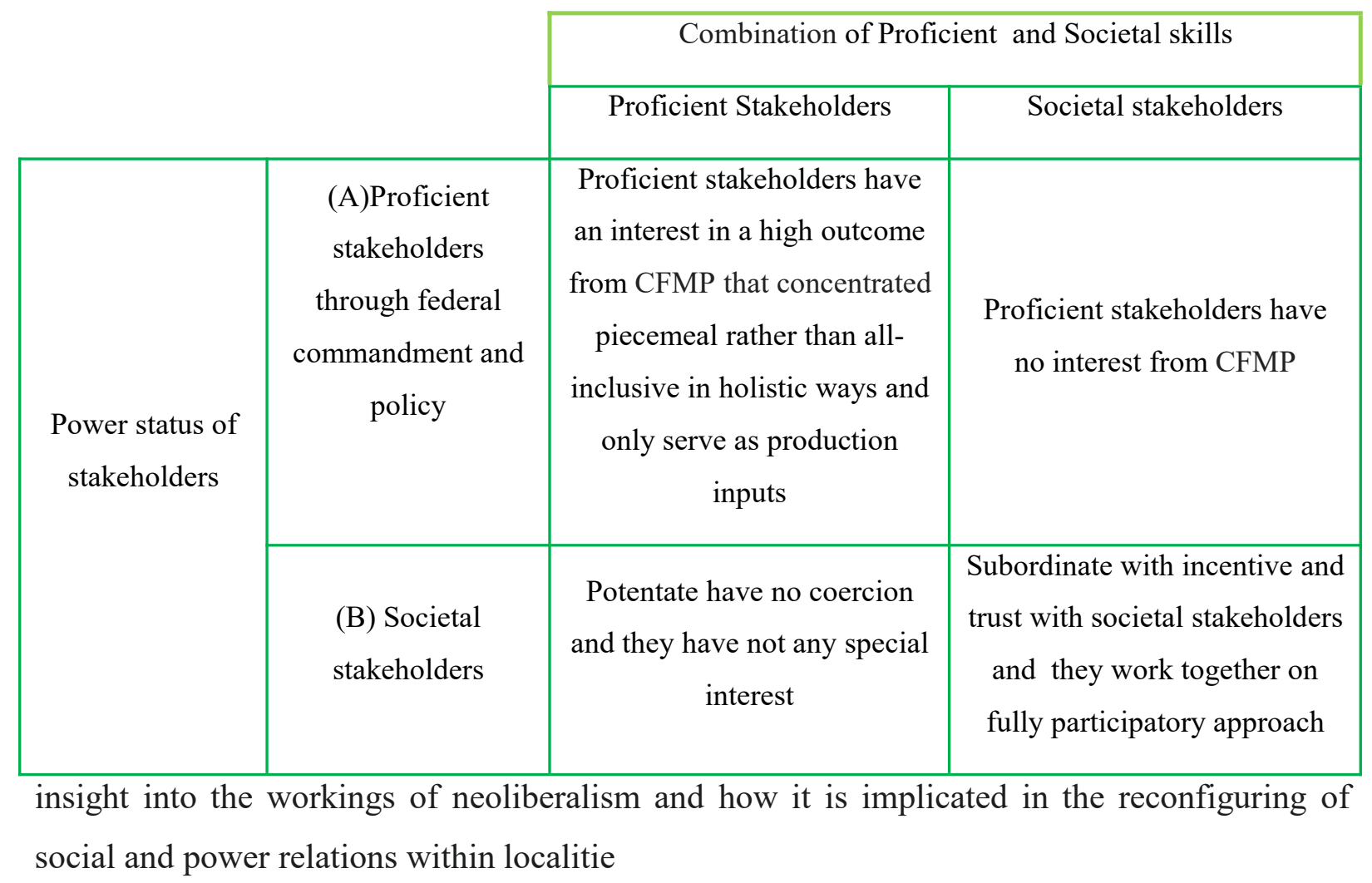

Figure 1: A conceptual model of stakeholders from CFUGs

The major assumptions of the conceptual model of stakeholders in Fig. 1 are as follows. First, in a power structure where the stakeholder is structured as shown proficient stakeholders ${ }^{1}$ 
have an interest in high outcomes, one would expect to find proficient stakeholders dominating the CFMP decisions through monopolisation of community Forestry resources through federal law and policy. The CFs is viewed as trade commodities and only serves as production inputs. The federal governments' laws and policy continue to emphasize of the CF for economic development rather than ecological stabilities. This would be reflected in the $\mathrm{CF}$ outcomes that favour proficient stakeholders and the willpower (coercion) of the potentate is against the societal stakeholders ${ }^{2}$ as well as subordinates. Second, in a community where CFUGs have a large proportion a combination of the proficient and societal stakeholders and the proficient stakeholders including authorised forest specialists have no interest in a specific benefits/outcome from the CFMP, the will of the subordinate is recognised and respected. One would expect to find the societal stakeholders trust will fully recognised and respects the needs and desires of societal stakeholders where Community's rights and people participation in CFMP have been fully recognized and accepted.

In summary Societal stakeholders are generally included in significant realms of institutions, policies, norms and systems and their services including in the preparation of the CFMP when authorised forest specialists have no interest in a specific benefits.

\subsection{CF Outcomes}

The costly state-controlled approach of central government towards local communities will play a vital and more active role. The main purpose of the reform was purportedly to shift responsibility from central government to local communities regarding increasing participation in NRM and conservation. Nepalese have predictably depended on community

forests for basic needs of firewood, timber, fodder including ecological outcomes (Malla et al., 2005). Those outcomes are achieved for the end-users through CFMP (Shackleton et al., 2002). However, this rhetoric shaped a different level of Managers and policy makers involved in CFMP and relationships between user organisations, central and provincial government forest specialists who are responsible to prepare, and control of CFMP implemented by CFUGs (Gilmore, 2016). The relationships are shown in Figure 2.

2 Non proficient stakeholders are regular stakeholders and disadvantaged who depend on CF for ecological outcomes. 


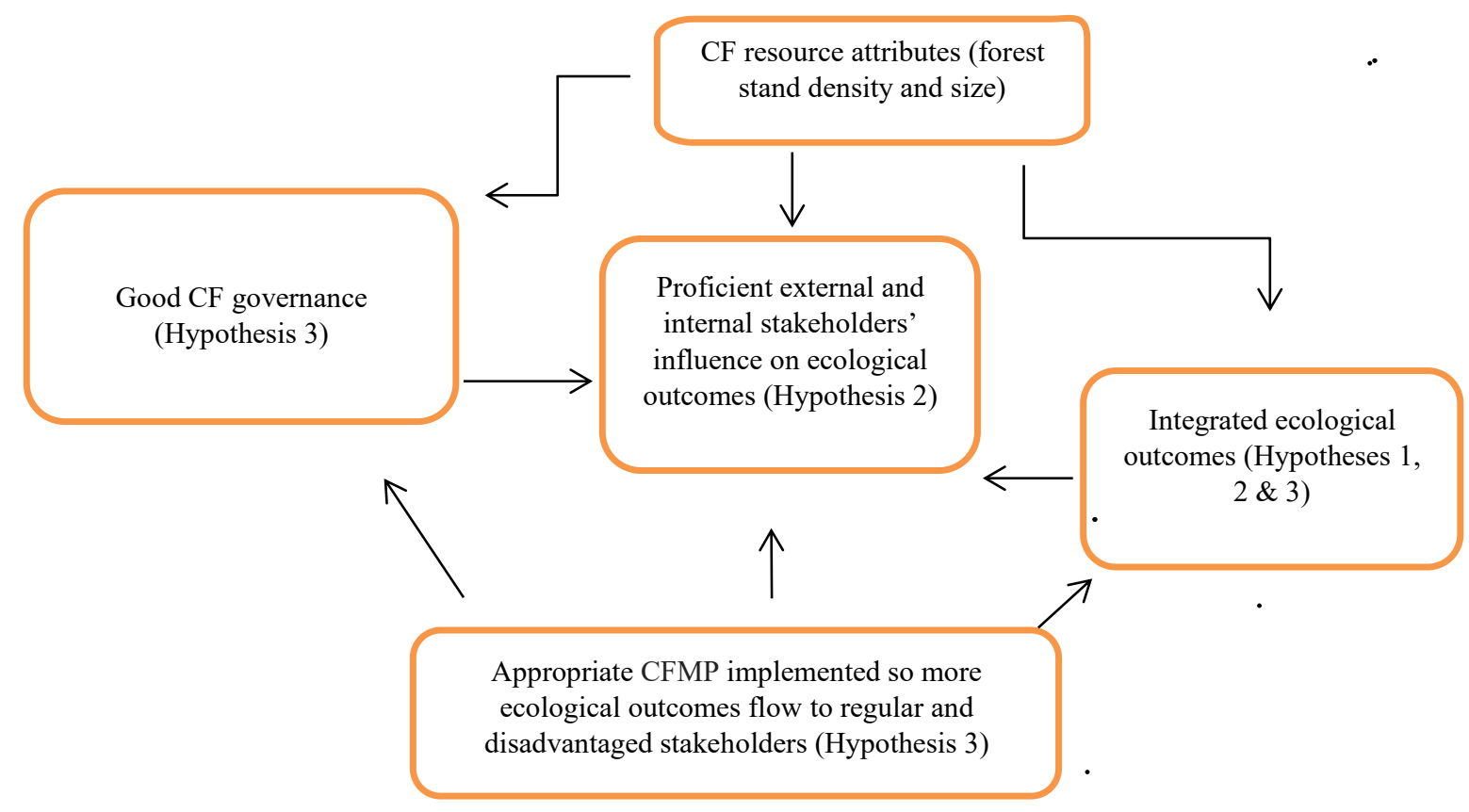

Figure 2 The empirical framework of power influence model in CFMP.

\subsection{Integrated Ecological Outcomes}

Forests provide support e.g., nutrient recycling, primary production and soil formation, which make possible food supply, flood regulation and water purification. The regulatory (e.g., carbon sequestration and climate regulation, habitat conservation, waste decomposition and detoxification and purification of water, and pest and disease control), provisioning (timber, firewood, fodder, food, medicine and fibre) and cultural services (non-material outcomes for people such as recreation, aesthetics and educational). These services are vital for all living beings not only humans. Bull et al. (2015) evaluated ecological performance empirically based on vegetation stand by an index of biodiversity intactness to link with the losses incurred by development. Hence, for effective monitoring of ecological systems to meet needs for biodiversity, science, ecosystem and humans, the desired outcomes are referred to as integrated ecological outcomes. The economic and social outcomes of CF will be explained in later articles because of space constraints.

\subsection{Community Forestry Resource Attributes for ecological outcomes}

CFMP and its active and wise full implementation are vital to ecological balance. This is clearly defined in the Constitution of Nepal (2015) part 4 article (51) Policies of the state (g) Policies relating to protection, promotion and use of natural resources: 6 . to maintain the 
forest area in necessary lands for ecological balance. Forest sector policy (2014) sustainable development of Chure, Inner Terai and Terai region of Nepal in regard to ecological balance, environmental sustainability through appropriate Plan (11) 2 (a)and (d) related to ecological sustainable plan development" clearly spell this out. However, these results in surveyed regions of the management plan of ecological balance in plain words are seen in activities. Section 4 explains the empirical model of CFMP regarding ecological outcomes.

\section{Empirical Model for Measuring CFMP Regarding Ecological Outcomes}

The literature review and conceptual model provide us with the foundation to formulate an empirical model to measure the CFMP particularly for the ecological outcomes. Problems relate to ecological outcomes that sometimes conflict with the visions and needs of societal groups in the society (Ahlborg and Nightingale, 2012). In addition, ecological outcomes are often acted out on the ground as violations of conserving rules, law and practices in a way that scale is produced and politicised, which reshapes and undermines the outcomes and management of socioecological factors. If the forest attributes are rationed particularly on a per household area of annual harvesting forest type, then it could be a better measurable technique of CFMP that hypothesizes enhancement of the ecological outcomes for end users of CFUGs as:

(i) Ecological outcome (Change) $\left(\mathrm{Y}_{\mathrm{i}}\right)=f$ (Ecological, socioecological, and environmental factors $^{3}$, for communities and other relevant explanatory variables explained in Table 1 to avoid the omitted variables problem) $\quad 1$

This study uses a regression method to examine the relationships. The generic relationship between the dependent and explanatory variables can be mathematically illustrated as follows:

$$
\mathrm{Y}_{\mathrm{i}}^{\mathrm{z}}=\beta_{0}^{\mathrm{z}}+\beta_{i j}^{z} X_{i j}^{z}+e^{z}
$$

Where: $Y_{i}^{z}$ represents the $\mathrm{z}$ response variables (ecological, environmental factors and socioecological factors associated with ecological outcomes in response to CF, including forest attributes like per household forest area, forest type, tree density, soil quality, water sources and quality, wildlife status, amenity and aesthetic value, and household socioecological factors including own land, number in household, level of education of

3 Ecological outcomes (outcomes), and socioecological and environmental benefit related variables. 
household in $\mathrm{i}$ forest user group; $\mathrm{Xj}$ represents the $j^{\text {th }}$ explanatory variable for the ith local CFUGs organisation; and the error term is $e^{z}$. Finally, $\beta_{0}{ }^{z}$ and $\beta_{j}{ }^{z}$ are, respectively, a constant term of the model and the coefficient of the variables.

\section{Data and Methods}

Nepal is topographically divided into three regions: the Himalaya to the north, the middle hills consisting of the Mahabharata Range and the Churia Hills and the includes the inner Terai and Terai to the south, $17 \%$ of total land area in Nepal (Nagendra, 2002). The Himalayas and foothills make up the northern border of the country and represent $16 \%$ of the total land area. Except for the Himalayas, the middle hills represent $67 \%$ of total land area. Most CF has been implemented in these two regions for four decades. For this study, random sampling was applied to select districts and study sites. There is several of random sampling technique of which case sampling was used. The special attributes of this sampling method are based on their likelihood of behaving like everyone else, which may include specialist knowledge of the research issue, or a capacity and willingness to participate in the research.

This method of sample selection assumes every household and region (Terai and Hill) in the nation could be selected with a predetermined probability. To get a representative study site and to meet our study's purpose, we practised typical case sampling under a stratified sampling method where households were characterized based on the socioeconomic status rich, medium, poor, and poorest. Nepal is diverse sociocultural and ethnically and contains various forest types in different geo-climatic zones. The Siraha, Saptari and Udaypur districts were selected because they represent the Mahabharata range, Churia Hills, the Inner Terai and Terai where a Community Forestry programme has been implemented. The districts represent all regions where CF programmes have been implemented so the findings can be applied widely to the other Terai, Inner Terai, hill and mountain districts of Nepal. We hypothesize a connection between ecological outcomes related data collected from the residents who have been active closely of 50 years of practical experience in these regions to observed ecological and environmental change. The data were collected by three main ways in three districts: (a) a household survey of 310 households including rich, medium, poor, and poorest (b) a survey of the Executive Committees (EC) of 31 CFUGs; and (c) secondary sources. 


\section{Results and Discussion}

The effectiveness of the CFMP is analysed using the perceptions of local stakeholders in CFUGs. The analysis focuses on the ecological outcomes from the perspective of local individual households. The influence of the power structure in the conceptual model (Fig. 1) in the preparation of the management plan of CF. This also provides the answer the research question, the selection of an appropriate model forest management plan that maximise the ecological outcomes. First, the descriptive characters of the collected data were used to determine results through the potential regression variables. Second, the data are analysed by regression analysis. It is believed that if a forest management plan is prepared and implemented with the optimum wise use, it helps balance ecological outcomes. The parameters for measuring the variables are increase, decrease, same and no idea, from the perspective of general stakeholders.

\subsection{Descriptive Findings}

Before analysing any data set collected from stakeholders' households regarding ecological outcomes, and from the perspective of societal stakeholders who maintain their livelihoods in the surrounding environment, it is important to understand the data. Descriptive statistics presents data in a meaningful way to understand what, if anything needs to be done to the data to prepare them for analysis (Fricker et al., 2019). This study focuses on a review of descriptive statistical analysis to prepare and support predictive analytics. It reviews methods to ensure that the data are prepared for analysis as well as the methods for combining or reducing variables to improve the results of predictive analytics. The variables that are significant from the descriptive analysis are incorporated into the regression analysis. The following variables are analysed through descriptive analysis and the significant ones selected for regression analysis. 


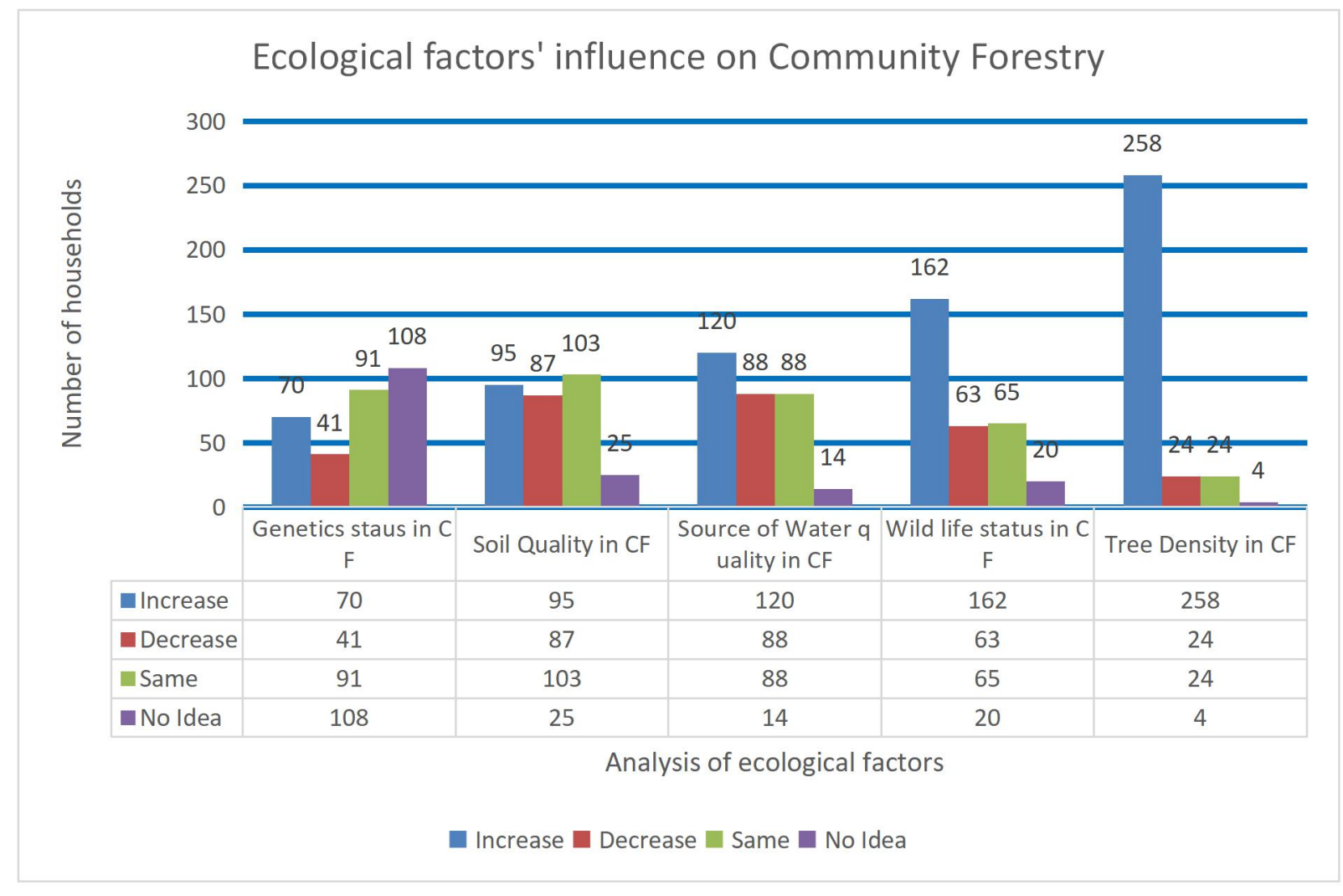

Figure 3 Analysis of Ecological consequences. Source: 310 Household data of 31Community Forestry 2019

\section{Tree Genetic Status}

All forest tree species, both broadleaf and conifer are well represented at all levels of protection from $\mathrm{CF}$ through local stakeholders. Additional protection and sampling from outlying and remote populations at the margin of the species' range would add more comprehensive representation for all aspects of Sal (Shorea robusta) and associated species' genetics conservation. Seventy households responded that tree genetics increased; 41 households responded that most of tree species genetics had decreased; 91 households responded that genetics status of several forest species were the same; and 108 households said they had no idea. Obviously, a genetics study is not simple. It needs design and lying out of high quality of trial plots and observing data over a period.

\section{Soil Quality}

Soil quality defines whether soils are in good condition containing a balanced amount of humus for current use that is also referred to as 'soil health' (Tripathi et al., 2020). The physical (porous, compaction, chemical (pH value) and biological (bacteria and earthworms) characteristics of different soils vary a greatly so different soils are suited to different uses. Of 
the households, 95, 87, 103 and 25 of 310 stated their view that soil quality increased, decreased, was the same, and no idea, respectively.

\section{Source of Water Quality}

The absolute level for a livelihood is defined as the total amount of water obtained from forest and environment sources (Damania et al., 2020).). Rich households obtain more absolute ecological outcomes but for the rich they represent a small share of their total benefits. As found elsewhere, the poorest poor, the disadvantaged and poor women obtain more of their ecological outcomes including the environment than agriculture -a consequence of their often landless status (Angelson and Dokken, 2015). Of the households, 120, 88, 88 and 14 of 310 responded that water quality increased, decreased, same and no idea, respectively.

\section{Wildlife status}

Pandit and Bevilacqua (2011) perceived improved local environmental conditions in the form of increased understorey regeneration, increased wildlife in the forests, and improved forest greenery (density). Of households responding wildlife population status, 162 said increased, 63 said decrease, and 65 households said the same and 20 responded they had no idea.

\section{Tree Density}

The above chart displays that 258 households responded that tree density has increased in last 10 years since CFMP was implemented under CFUGs, 24 households observed tree density had decreased, 24 households said that tree density was same and 4 households said they had no idea. Note that 258 of 310 households responded that tree density had increased. This variable is statistically significant. Hence, it could be suitable variable to for econometric analysis. 


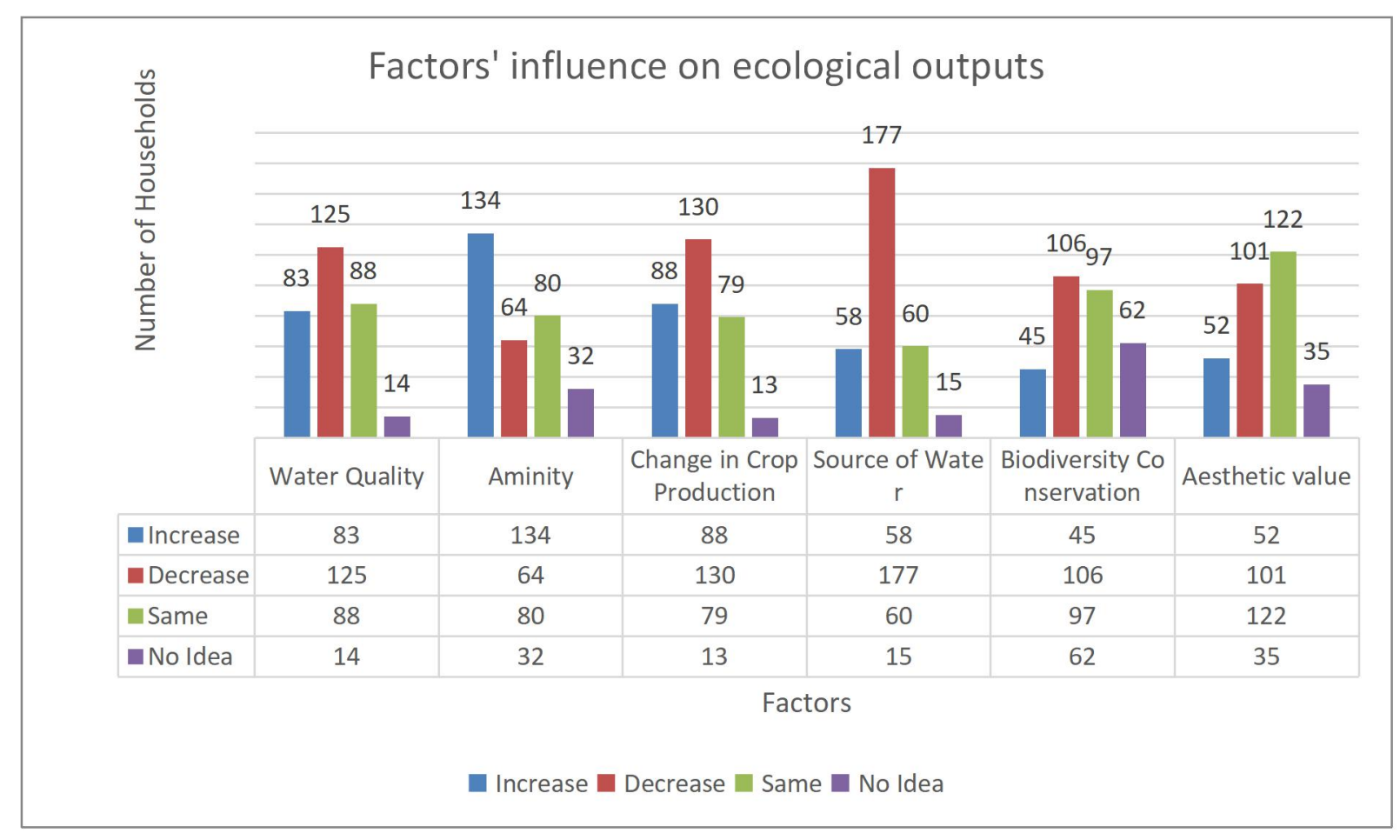

Figure 4 An Analysis of Ecological Factors in Nepal's Forests

Source: Household level data of 31 Community Forestry

\section{Water Quality}

Water quality at the community level describes the condition of water, including chemical, physical, and biological attributes usually with respect to its ability as a water body to support all appropriate beneficial uses. Beneficial uses are the ways in which water is used by humans and wildlife, drinking water and fish habitat. Water quality also determines natural processes in the environment and determines human impacts on ecosystems. At the community level, of 310 households, 125 responded that the quality of water has decreased and 83 households stated it had increased.

\section{Amenity}

This study investigates the impact of environmental amenity on local stakeholders' skill aggregation. In the context of environmental economics, an environmental amenity can include access to clean air or clean water, or the quality of any other environmental good that may reduce adverse health effects for residents or increase their economic welfare (Coglianese and Starobin, 2020). The amenity value is clear in Fig. 2; of 310 households, 134 households expressed the view that amenity values had increased and 64 household that it had decreased.

\section{Changes in Crop Production}


Farmland has generated negative effects on rural societies eco-environmentally and sociologically and affected on the local population and the whole society in terms of the production of goods (e.g., foods, feed, fibre), as well as services provided by the multifunctionality (e.g. sociocultural practices, values and norms) of the agricultural landscape (Chaudhary et al., 2020). The 88 (28.38\%) households responded increase, 130 households $(41.93 \%)$ decrease 79 (25.48\%), same and 13(4.19\%) households responded in the crop production no idea respectively in out of 310 households.

\section{Water Sources}

There is very limited research on water sources in the Terai region of Nepal. For most districts in the region, underground water flow has been wiped out or is depleted because of the loss of vegetation and natural forest on Chure and hills. Kharel and Shukla (2020) found depletion in groundwater and therefore progressive reduction in the discharge of shallow tube wells in Jhapa district in Nepal. This study shows that 58 interviewees (18.71\%) responded that there were increased of sources of water whereas $57.1 \%$ believed that water sources had decreased, and $19.35 \%$ reported water sources were same in last 10 years. The water source impact from ecological outcomes affecting water use includes changed lifestyle, economy, technology, and farming system that negatively affect the livelihoods of local people.

\section{Biodiversity Conservation}

Biodiversity broadly refers to the variety of life at every hierarchical level and spatial scale of biological organisations: genes within populations, populations within species, species within communities, communities within landscapes, landscapes within biomes, and biomes within the biosphere (Wilson, 1988). Biodiversity includes things fundamental to our health like fresh water, clean air and food, as well as many other products such as timber, fibre, and medicinal plants. Biodiversity provides various other important goods and services such as cultural, recreational, and spiritual nourishment that play an important role in maintaining our personal life as well as social life. Hence biodiversity plays a crucial role in securing human current and future lives. This study found that $14.51 \%, 34.9 \%, 31.29 \%$ and $20 \%$ of respondents increased, decreased, was the same and no idea about biodiversity, respectively. 


\section{Aesthetic Values}

In this study, aesthetics refers to a branch of philosophy that deals with the nature of beauty. Aesthetic value is a value judgement based on the appearance of an object and the emotional responses it evokes. It is difficult to objectively assess aesthetic value. For example, the image of ecological stability differed to a great extent from the image of a general forest Plan. The attractiveness of a young forest, i.e., its perceived aesthetic beauty, was mostly correlated with a sense of easy access and added more aesthetic value. Thus, the presence of deadwood, understorey and high stand density were the most important factors in a negative attitude towards the forest. Single tree characteristics (height, diameter) showed a small but significant positive correlation with aesthetic quality. Of the households that responded, $16.77 \%$ said increased aesthetic value; $32.58 \%$ stated decreased; $39.35 \%$ respondents stated the same aesthetic value and 11, $29 \%$ respondents had no idea about the aesthetic value over the last 10 years. The results also indicate a correlation between aesthetic and ecological outcomes within a group of respondents. This finding supports Golivets (2011) who suggests a positive influence of a good-looking forest on the overall public attitude towards sustainability of forest management practices.

\section{Summary}

A two-tail $t$-test assuming unequal variances was conducted to analyse whether the paired groups are statistically different between each set. The socioecological and forest attributes with ecological variables were statistically significant by various descriptive and t-test analyses. The overall results indicate that the variables listed in Table 1 were suitable for econometric analysis.

The dependent variable is ecological outcomes over 10 years after handing over the forest to CFUGs. Regressions were done for ecological outcomes. Ecological outcomes were observed by the local household heads who participated in an interview. The potential explanatory factors determining ecological outcomes (the dependent variable), as recommended from the descriptive analysis for further analysis in a regression model, were examined in a binary choice model. The explanatory variables Table 1 were examined in different functional forms (i.e., logarithmic or raw) as well as in their interactions. A multi-collinearity test was conducted to see if there was any collinearity among the explanatory variables. 


\subsection{Regression Findings}

The data set from the research sites were analysed by a binomial logistic regression that indicates the probability that an observation falls into one of two categories of a dichotomous dependent variable based on one or more independent variables. The p-value and coefficients in regression analysis is working together to tell us which relationships in the model are statistically significant and the nature of those relationships.

Table1 The dependent and independent (explanatory) variables for econometric analysis

\begin{tabular}{|c|c|}
\hline Dependent Variable & Variable Description \\
\hline Ecological outcomes & $\begin{array}{l}\text { Ecological outcomes were observed by the household heads over } 10 \\
\text { years experiences since the handing over the Community Forestry to } \\
\text { local communities, If the experience of interviewees is yes } 1 \text {, otherwise } \\
0 \text {. }\end{array}$ \\
\hline Independent Variable & Description of variables \\
\hline \multicolumn{2}{|l|}{ Socioecological variables } \\
\hline AgeHHH & Age of Household Head who participated in interview \\
\hline HHNo & Number of Households in CFUGs \\
\hline Own land & If households have own land includes Khet, Bari 1, otherwise 0 \\
\hline Ed level & $\begin{array}{l}\text { Level of education such as illiterate, primary, middle, high School, } \\
\text { intermediate, bachelor degree and above }\end{array}$ \\
\hline Cow & Number of cows by household \\
\hline Buffalo & Number of buffalos by household \\
\hline Goat & Number of goats by households \\
\hline Gender & If household head male 1 , otherwise 0 . \\
\hline \multicolumn{2}{|c|}{ (b) Forest attributes with Environmental variable } \\
\hline CFArea & Community Forestry area in hectares \\
\hline BroadlF & Broad leaf forest type composition $\%$ broad leaf species \\
\hline CONFER & Conifer forest type composition $\%$ coniferous species \\
\hline Wildlife & $\begin{array}{l}\text { Change in population of wildlife if increase } 1 \text {, same } 2 \text {, decrease } 3 \text {, no } \\
\text { idea } 4\end{array}$ \\
\hline
\end{tabular}




\begin{tabular}{|c|c|}
\hline Soil quality & If increase 1, same 2, decrease 3, no idea 4 \\
\hline CropPro & Crop production per unit area: if increase 1, same 2, decrease 3, no idea \\
\hline SWater & Source of water: If increase 1, same 2, decrease 3, no idea 4 \\
\hline Swaterqt & Source of water quality: If increase 1, same 2, decrease 3, no idea 4 \\
\hline Biodiver & Change in Biodiversity: If increase 1, same 2, decrease 3, no idea 4 \\
\hline TreD & Change in Trees density If increase 1, same 2, decrease 3, no idea 4 \\
\hline Genetic & $\begin{array}{c}\text { Improve in Genetic of Species: If increase 1, same 2, decrease 3, no idea } \\
4\end{array}$ \\
\hline
\end{tabular}

The coefficients describe the mathematical relationship between each independent variable and the dependent variable. Model building took several steps. First, non-significant variables were deleted from the model in a step-by-step process until the model was stable. Since variable deletion creates a nested model, the model stability was examined by using the Chisquare test for significant difference of $-2 \log$ likelihood ratios as suggested by Osth et al. (2017) and Agresti and Finlay (2009). The maximum log pseudolikelihood = -147.13417; Wald $\mathrm{Chi}^{2}(9)=40.96$ and restricted $\log$ likelihood -156.3723 ; pseudo $\mathrm{R}^{2} \cdot 0.1350$ and Prob $>$ chi $^{2}=0.0000$. The dependent variable is ecological outcomes; the rest are explanatory variables. The regression analysis findings are presented in Table 2. 
Table 2 Regression results of variables on ecological outcomes

\begin{tabular}{|c|c|c|c|c|c|}
\hline \multicolumn{3}{|c|}{ Logistic regression } & Number of obs & $=$ & 310 \\
\hline \multicolumn{3}{|r|}{ Wald $\operatorname{chi}^{2}(9)$} & $=40.96$ & & \\
\hline \multicolumn{3}{|r|}{ Prob $>\operatorname{chi}^{2}$} & $=0.0000$ & & \\
\hline \multicolumn{3}{|c|}{ Log pseudolikelihood $=-147.13417$} & Pseudo $\mathrm{R}^{2}$ & $=$ & 0.1350 \\
\hline \multicolumn{6}{|c|}{ [95\% Conf. Interval] } \\
\hline Variable & $\mathrm{b}$ & & Std error & & $\mathrm{z}$ value \\
\hline LnHHNO & 0.517 & & 0.156 & & -2.19 \\
\hline LnFPCArea & 1.684 & & 0.398 & & 2.21 \\
\hline LnBroadlF & 4.241 & & 4.036 & & 1.52 \\
\hline OwnBari & 1.598 & & 0.367 & & 2.04 \\
\hline AgeHHH & 1.025 & & 0.014 & & 1.76 \\
\hline EdLevel & 2.125 & & 0.379 & & 4.23 \\
\hline Cow & 1.142 & & 0.098 & & 1.55 \\
\hline Buffalo & 0.918 & & 0.069 & & -1.13 \\
\hline Gender & 1.708 & & 0.510 & & 1.79 \\
\hline cons & 0.001 & & 0.004 & & -1.64 \\
\hline
\end{tabular}

Number of Households in Community Forestry User Groups (LnHHNO) is statistically positively significant at the $3 \%$ level suggesting that the community forestry's contributions to ecological outcomes have broadened in CF through CFMP's implementation. This result is similar to Chaudhary et al. (2019) who indicated that ecological/environmental sustainability around and in CFs.

Log per household area of community forestry (LnPHHArea) is statistically positively significant at the $1 \%$ level. It indicates that as per household forest area increases, the ecological outcomes increase towards a friendly environment for the livelihoods of local 
stakeholders. The results support Jhariya et al. (2019) who argue that ecological problems per household increase with a sustainable forest management.

Broad leaf forest Type (BROADLF) is statistically and positively significant at $1 \%$ level. It indicates that broadleaf forest with a high value timber Sal (Shorea robusta) and associate species managed with an appropriate silvicultural system increases the ecological sustainability positively. This result is similar to the finding of Moe and Owari (2020) that the main common characteristics of high-value timber species were increased by tree density.

Amendment date of Community Forest Management Plan (Amendate) is statistically positively significant at the 5\% level. It is essential for managing the long-term sustainability of socioecological system for human wellbeing. However, the significance level indicates that ecological sustainability and human well-being are absolutely based on the appropriate amendments of CFMP in the 10 year periods that led to CF toward sustainability. This result is like Hossain et al. (2020) who argue that findings contribute to the management of the deltaic ecological system.

Level of Education (Edlevel) is statistically positively significant at the $1 \%$ level. This indicates that education level seems to have little effect in explaining inhabitants' environmental concerns measured in this study. Educated household heads perceive increasing ecological enhancement around the CF periphery because of CF management in Nepal.

Age of Household Head (AgeHH) is positively statistically significant at the $8 \%$ level. This indicates that senior household age group perceived more enhancements of ecological outcomes in CF fringe neighbourhoods. The reason behind this could be that household heads have long experience in maintaining their livelihood and the ecological outcomes, forest resources and their products along with amenity, quality of soil, water sources, quality which lead the positive change in ecological endeavour of the region.

Gender is statistically positively significant at the $7 \%$ level. This indicates that gender, particularly active women's participation in the preparation and implementation of the CFMP has functioned a positive change in the ecological components in the Terai and Inner Terai in Nepal. Most studies have found this in the hill and mountain regions of Nepal. There has been very limited research conducted in this region. Wagle et al. (2017) argue that gender dynamics create employment for women to enter and progress in forestry to 
influence the decision-making power through institutional, legislative, normative, and policy formulation measures.

\section{Conclusion}

The descriptive correlated variables sources of water quality (57.1\%), wildlife status and tree density, change in crop production, amenity, were seen as significant that increase intensity whereas biodiversity conservation negatively significant $(34.9 \%)$ in the perception of the local stakeholders. The findings of regression analysis is about the ecological outcomes are linked to socioecological factors such as number of households, age of household head, level of education, and gender in CFUGs were positively significant. In addition, forest attributes with environmental factors (variables) forest area per household, forest type particularly broadleaf forest type and amendment of CFMP were also important and also positive significantly correlated with the ecological outcomes. In general, socioecological related variables as the proportion of educated households, gender mainly who uses forest resources had experienced ecological factors were positively active over last 10 years were likely to favour the positive significant changes in ecological status around the CF and surrounding environments. The forest attributes interrelated variables: CF area per household, amendment of CFMP, forest type broadleaf was positively correlated with positive ecological outcomes. The findings support the hypothesis that representation of higher per household forest area and educated groups on the user assembly allows them to influence the ecological outcomes that, in turn, increases the ecological benefits they receive from $\mathrm{CF}$.

Finding also correlated with a conceptual model of stakeholders from CFUGs (Figure 1B) also support the positive effect outcomes for the ecological outcomes in Nepalese society. Moreover, the findings support the hypothesis the socioecological, forest attributes and ecological associated factors related to external and internal actors including forest experts who have not any significant influence on the ecological outcomes of Community Forestry when (B) component of conceptual model of societal stakeholders from CFUGs will be applied. The findings of this study contribute to designing and implementing both CFMP and sustainable ecological management to improve CFMP with specific ecological activities that could provide policy recommendations for improving ecological sustainability, livelihoods, and human well-being in Nepalese forest governance. 


\section{Acknowledgements}

The authors gratefully thank EC and CFUG members who provided valuable time that allowed the collection of information from households and CFUGs. The authors also DFOs Mr Bishnu Pd Acharya, Mr Dan Bahadur Shrestha, Mr Dhirendra Pd Sigh, Mr Upendra Patel of the Udaypur Gaighat, Katari, Sapatari and Sirha Divisional Forest Offices, and their teams for supporting the collection of information from CFUGs. The authors acknowledge Support For Development (SFD), a New Zealand NGO for providing the funds that allowed the data collection. This research article is published on behalf of that organisation.

\section{References}

[1] Acharya, R.P.; Maraseni, T.N.; Cockfield, G. (2019). Local Users and Other Stakeholders' Perceptions of the Identification and Prioritization of Ecosystem Services in Fragile Mountains: A Case Study of Chure Region of Nepal. Forests 2019, 10, 421.

[2] Adhikari, B. and Agrawal, A. (2013). Understanding the Social and Ecological Outcomes of PES Projects: A Review and an Analysis. Conservation and Society 11(4), 359-374

[3] Agrawal A., Cashore, B., Hardin R., Shepherd, G., Benson C., Miller D. (2013). Economic contributions of forests. Background paper prepared for the United Nations Forum on Forests April 8-19, Istanbul, Turkey

[4] Agresti, A., \& Finlay, B. (2009). Statistical methods for the social science (Fourth Ed): Macmillan Inc, USA.

[5] Ahlborg, H., and A. J. Nightingale. (2012). Mismatch between scales of knowledge in Nepalese forestry: epistemology, power, and policy implications. Ecology and Society 17(4): 16. http://dx.doi.org/10.5751/ ES-05171-170416

[6] Anderson, K. and Agrawal, A. (2011). Inequalities, Institutions, and Community Forestry. Global Environmental Changes, 21, 866-875.

[7] Angelsen, A. and Dokken, T. (2015). Environmental reliance, climate exposure, and vulnerability: a cross-section analysis of structural and stochastic poverty. World Bank Policy Research Paper Number, 7474 (2015)

[8] Baral, S. Khadka, C. \& Vacik, H. (2019a) Using MCA tools for evaluating communitymanaged forests from a green economy perspective: lessons from Nepal, International Journal of Sustainable Development \& World Ecology, 26:8, 672683, DOI: $10.1080 / 13504509.2019 .1652858$ 
[9] Baral, S., Meilby, H., Chhetri, Khanal, B.B. (2019b).The Contested Role of Management Plans in Improving Forest Conditions in Nepal's Community Forests. International Forestry Review21 (1),37-50 DOI: https://doi.org/10.1505/146554819825863799

[10] Brockerhoff, E.G., Jactel, H., Parrotta, J.A. (2008). Plantation forests and biodiversity: oxymoron or opportunity? Biodiversity Conservation 17, 925-951 https://doi.org/10.1007/s10531-008-9380-x

[11] Bull, J.W. Hardy, M. J. Moilanen, A. Gordon, A. (2015). Economic and Ecological Outcomes of Flexible Biodiversity Offset Systems, Biological Conservation, 27(6) 34-44

[12] Baynes, J., Herbohn, J., Smith, C., Fisher, R., Bray, D.(2015).Key factors which influence the success of community forestry in developing countries. Global Environmental Change, 35(1), 226-238, doi.org/10.1016/j.gloenvcha.2015.09.011.

[13] Cedamon, E., Nuberg, I., Pandit, B.H. (2019). Adaptation factors and futures of agroforestry systems in Nepal. Agroforest System 92, 1437-1453 (2018). https://doi.org/10.1007/s10457-017-0090-9

[14] Charmakar, S., Oli, B.N., Joshi, N.R. (2021) Forest Carbon Storage and Species Richness in FSC Certified and Non-certified Community Forests in Nepal. Small-scale Forestry (2021). https://doi.org/10.1007/s11842-020-09464-3

[15] Coglianese, C. and Starobin, S. (2020). Social Science and the Analysis of Environmental Policy of Penn, Inst for Law \& Econ Research Paper No. 20-12. Available at SSRN: https://ssrn.com/abstract $=3537708$

[16] Damania, R. Joshi, A. Russ, J. (2020). India's forests - Steppingstone or millstone for the poor? World Development,125, 0305-750 doi.org/10.1016/j.worlddev.2018.11.007

[17] DFRS (2015). State of Nepal's Forests. Forest Resource Assessment (FRA) Nepal, Department of Forest Research and Survey (DFRS). Kathmandu, Nepal.

[18] Dobias, R. (2018). Climate Change in South Asia. Asian Development Bank.

[19] Dwyer, Janet C and Berriet-Solliec, Marielle and Lataste, François-Gaël and Short, Christopher J and Maréchal, Anne and Hart, Kaley (2018) A Social-Ecological Systems approach to enhance sustainable farming and forestry in the EU. EuroChoices. pp. 1-8. (In Press)

[20] FAO (2010) Planted forests in sustainable forest management: A statement of principles. Food and Agricultural Organisation, Rome

[21] Fricker, R. D., Burke, K., Han, X., Woodall, W. H. (2019). Assessing the Statistical Analyses Used in Basic and Applied Social Psychology After Their p-Value Ban. The American Statistician,73(1),374-384 doi: 10.1080/00031305.2018.1537892 
[22] Gilmour, D. (2016). Forty years of community-based forestry: a review of its extent and effectiveness. FAO Forestry No.176, 1-168.

[23] Golivets,M. (2011). Aesthetic Value of Forest Landscapes. Master thesis number 177. Swedish University of Agriculture Science. Southern Forest Research Centre, Alanarp.

[24] GON (2015).The Constitution of Nepal (2015).Ministry of Law, Justice and Parliamentary affairs. Government of Nepal.

[25] GON (2015). Forest Sector Policy. Ministry of Forest and Environment, Nepalese Government.

[26] Hoffmann, S., Jaeger, D., and Shuirong, W. (2018). Adapting Chinese Forest Operations to Socio-Economic Developments: What is the Potential of Plantations for Strengthening Domestic Wood Supply? Sustainability 2018, 10, 1042; doi:10.3390/su10041042

[27] Hossain, Md Sarwar, Ramirez, J., Szabo, S., Eigenbrod, F. Johnson, F. Speranza A., Chinwe I., Dearing, J.A. (202). Participatory modelling for conceptualizing socialecological system dynamics in the Bangladesh Delta. Regional Environmental Change,20(1),28-29. https://doi.org/10.1007/s10113-020-01599-5

[28] Humphries, S., Andrade, D.F.C., McGrath, D., Dantas, J. B.(2020). Searching for winwin forest outcomes: Learning-by-doing, financial viability, and income growth for a community-based forest management cooperative in the Brazilian Amazon, World Development, 125 (1), 104336://doi.org/10.1016/j.worlddev.2018.06.005

[29] Jessica M. C., Antony S. C.(2011).Using analyses of public value orientations, attitudes and preferences to inform national forest planning in Colorado and Wyoming, Applied Geography,31(2),393-400, doi.org/10.1016/j.apgeog.2010.10.001.

[30] Jhariya M.K., Yadav D.K., Banerjee A., Raj A., Meena R.S. (2019) Sustainable Forestry Under Changing Climate. In: Jhariya M., Banerjee A., Meena R., Yadav D. (eds) Sustainable Agriculture, Forest and Environmental Management, 285-326 Springer, Singapore. DOI: https://doi.org/10.1007/978-

[31] Kharel, T.P. and Shukla, A. (2020). Stresses on Water Availability Resulting From Climatic Variability in Eastern Terai : A Case Study of Gauradaha VDC in Jhapa District. International Journal of Multidisciplinary Sciences and Advanced Technology 1(2), 6682 C. http://www.ijmsat.com

[32] Kumar,M., Singh,M.P., Singh,H., Dhakate, P.M. \& Ravindranath, N.H. (2020) Forest working plan for the sustainable management of forest and biodiversity in India, Journal of Sustainable Forestry, 39:1, 1-22, DOI: 10.1080/10549811.2019.1632212 
[33] Krott, M., Bader, A., - Schusser, C., Devkota, R., Maryudi, A., Giessen, L., Aurenhammer, H., (2014). Actor-centred power: The driving force in decentralised community-based forest governance. Forest Policy and Economics,49, 34-42

[34] Limbu D.K., Rai B.K., Rai K.K. (2020) Livelihood and Carbon Management by Indigenous People in Southern Himalayas. In: Shang Z., Degen A., Rafiq M., Squires V. (eds) Carbon Management for Promoting Local Livelihood in the Hindu Kush Himalayan (HKH) Region. Springer, Cham, https://doi.org/10.1007/978-3-030-205911 4

[35] Malla, Y. B., Neupane, H. R., Branny, P. (2005). Why are no poor people benefiting more from community forestry? Journal of Forest and Livelihoods 3(1), 78-91.

[36] MFS (2015). STATE OF NEPAL'S FORESTS. Ministry of Forests and Soil Conservation Department of Forest Research and Survey Forest Resource Assessment Nepal.

[37] MoFSC (2014). Nepal National Biodiversity Strategy and Action Plan 2014-2020 Ministry of Forests and Soil Conservation, Kathmandu, Nepal. [Google Scholar]

[38] Moe, K. T. and Owari, T. (2020). Sustainability of High-Value Timber Species in Mixed Conifer-Broadleaf Forest Managed under Selection System in Northern Japan. Forests, 11(5), 484; https://doi.org/10.3390/f11050484

[39] Osth, A. F., Dennis, S., Heathcote, A. (2017). Likelihood ratio sequential sampling models of recognition memory, Cognitive Psychology, 92,101126 .doi.org/10.1016/j.cogpsych.2016.11.007

[40] Ostrom, E. (1999). Copping with the strategies of the commons. Annual review of Political Science.2, 493-535

[41] Pandit, R. Bevilacqua, E, (2011).Forest Users and Environmental impacts of community Forestry in the hills of Nepal Forest Policy and Economics, 13(5), 345-352

[42] Poudyal, B.H.; Maraseni, T.; Cockfield, G. (2020) Scientific Forest Management Practice in Nepal: Critical Reflections from Stakeholders' Perspectives. Forests 2020, 11, 27.

[43] Sapkota, L.M., Dhungana, H., Poudyal, B.H. (2020). Understanding the Barriers to Community Forestry Delivering on its Potential: An Illustration from Two Heterogeneous Districts in Nepal. Environmental Management. https://doi.org/10.1007/s00267-019-01224-0

[44] Shackleton, S., Campbell, B., Wallenberg. Edmunds, D. (2002). Devolution and Community-Based Natural Resource Management: Creating Space for Local People to 
Participate and Benefit? Overseas Development Institute, London (Natural Resource Perspectives) 76

[45] Spies, J., Devisscher, T., Bulkan, J., Tansey, J., Griess, V.C. (2020). Value-oriented criteria, indicators and targets for conservation and production: A multi-party approach to forest management planning, Biological Conservation,230 (1), 151168doi.org/10.1016/j.biocon.2018.11.022.

[46] Sultana, P., Thompson,P.M., Paudel, N. S. Pariyar, M. \& Rahman, M. (2019) Transforming local natural resource conflicts to cooperation in a changing climate: Bangladesh and Nepal lessons, Climate Policy, 19:sup1, S94S106, DOI: $10.1080 / 14693062.2018 .1527678$

[47] Tripathi, S., Srivastava, P., Devi, R.S., Bhadouria,R.(2020).Chapter 2 - Influence of synthetic fertilizers and pesticides on soil health and soil microbiology, Editor(s): Majeti Narasimha Vara Prasad, Agrochemicals Detection, Treatment and Remediation,Butterworth-Heinemann,25-54 https://doi.org/10.1016/B978-0-08-1030172.00002-7.

[48] Tudoran, G. M., Zotta, M.(2020).Adapting the planning and management of Norway spruce forests in mountain areas of Romania to environmental conditions including climate change. Science of The Total Environment, 698(1), 133776 doi.org/10.1016/j.scitotenv.2019.133761

[49] Wagle, R., Pillay, S., Wright, W. (2017). Examining Nepalese Forestry Governance from Gender Perspectives. International Journal of Public Administration, 40 (3), 205-225 doi: $10.1080 / 01900692.2015 .1091015$

[50] Wilson, J.B.(1988). Shoot Competition and Root Competition. Journal of Applied Ecology, 25(1), 279-296 